\title{
Implementing Critical Thinking Tasks to Fostering English Learners' Intercultural Communicative Competence in a Genre-based Learning Environment
}

\author{
Luis Fernando Gómez-Rodríguez ${ }^{1}$ \\ ${ }^{1}$ Language Department, Universidad Pedagógica Nacional de Colombia, Bogotá, Colombia \\ Correspondence: Luis Fernando Gómez-Rodríguez, Language Department, Universidad Pedagógica Nacional de \\ Colombia, Bogotá, Colombia.
}

Received: October 21, 2018 Accepted: November 16, 2018 Online Published: November 20, 2018

doi: 10.5539/elt.v11n12p154 URL: https://doi.org/10.5539/elt.v11n12p154

\begin{abstract}
The development of intercultural communicative competence in EFL (English as a Foreign Language) education in many countries is still a difficult goal to achieve. EFL teachers and learners require more tangible and concrete methodological approaches to foster this important competence in the classroom. Therefore, this reflection article aims at proposing the use of genre-based learning as a significant communicative language approach to foster English learners' intercultural communicative competence (ICC) through a Sequence of Critical Thinking Tasks. Through two samples of genres, the article explains how the skills of discovery, of interpreting, and of relating, contained in the concept of ICC, can be articulated, complemented, and enhanced gradually through a set of more specific Critical Thinking Tasks. These mental skills can be useful to help learners understand, discover, interpret, and evaluate critically elements of deep culture that appear in different documents, genres, or texts produced by English-spoken cultures, other language communities, and learners' own culture. Doing critical thinking tasks through genre-based approach can constitute a preliminary but significant step to enhance English learners' critical intercultural awareness in EFL learning environments.
\end{abstract}

Keywords: genre-based approach, intercultural competence, English learners, critical thinking tasks

\section{Introduction}

During the past twenty years, intercultural communicative competence (ICC) has become a main teaching goal and a research topic in EFL (English as a Foreign Language) education. This field has become aware that English learners should not only learn linguistic rules and communicative functions as encouraged by the tenets of communicative language teaching, but also recognize, understand, and appreciate cultural patterns, viewpoints, and beliefs of learners' own culture, target English-speaking cultures, and other language communities (not only the ones that speak English), in this growing globalized world (Kramsch, 1993; Fantini, 1999; Knutson, 2006; Moeller \& Nugent, 2014). However, despite the general interest in ICC, the truth is that the intercultural dimension in real practice has failed in EFL communicative classrooms (Crozet \& Liddicoat, 2000; Dogankay-Aktuna; 2005; Hesar, Konka, \& Sarfsaz, 2012) because of several serious disadvantages. The first one relies on the fact that many EFL teachers think that they lack appropriate knowledge and teaching approaches to teach contents of the Anglophone or other foreign cultures. They find it difficult to grasp and promote the apparent intangible components/skills of ICC, and think they are neither English-native speaker, nor members of English or other language communities to be entitled to teach their cultures. These issues have been investigated by Young and Sachdev (2011) and Gu (2016).

The second limitation is that many EFL learners lack opportunities to interact with members of other cultures in real life situations, impeding them to experience and foster ICC naturally (Pauwels, 2000). For instance, most of EFL learners who live in Latin-American Spanish-speaking countries, namely Colombia, Mexico, Chile, Peru, and Argentina, lack exposure to authentic intercultural communication outside the classroom because the only direct contact with the foreign language is in the English class, scheduled few hours per week. In these countries, most of EFL learners never have authentic intercultural interaction with members of the target culture(s) or other world cultures through English as foreign or a lingua franca (used in intercultural communication for speakers of different first languages) (Seidlhofer, 2005). 
A third difficulty is an apparent lack of teaching materials to address cultural contents in the language classroom as teachers rarely observe and evaluate how instructional materials such as textbooks, documents, books, the Internet, videos, and even popular songs can be useful to foster ICC (Sercu, 2006). TV shows and movies are also important means to learn about the Anglo-Saxon culture and other world cultures. However, teachers mainly use these documents or genres to learn linguistic rules and to practice communicative functions, disregarding the intercultural properties in them.

To this situation is added the fact that, if cultural contents are integrated in the English classroom, the focus of study are elements of surface culture (Hinkel, 2001) or explicit culture (Shaules, 2007) such as holidays, food, landmarks, and great achievements of important people, which only represent the observable, well-recognized, and static icons of native and the target cultures. It is evident that knowing these representative and visible forms of culture will never prepare EFL learners to deal with intercultural relationships. Being intercultural means confronting elements of deep culture such as social behaviors and norms, lifestyles, politeness, as well as personal and collective ideologies about values, class, race, gender, money, education, work, and human rights, which can either produce positive intercultural experiences (understanding and tolerance), or negative experiences (conflict, confusion, and culture shock) in actual communication. Therefore, EFL teachers may find it difficult to not only teach English, but also to help learners identify, understand, and deal with invisible and complicated meanings of deep culture, since many learners cannot hold intercultural interactions with citizens from the Anglo-Saxon culture or other cultures of the world.

Because of these disadvantages in EFL contexts, this reflection article proposes and examines how English teachers can actually promote ICC development more tangibly with instructional materials they often use in the language classroom by putting into practice the principles of genre-based approach and the support of critical thinking tasks. The articulation of these theoretical perspectives aim at helping teachers with practical pedagogical proposals on how they can include cultural contents and enhance ICC easier and more purposely in the communicative language classroom.

\section{Theoretical Framework}

\subsection{Genre-Based Approach}

Genre-based approach or text-based approach is a trend of communicative language teaching that "sees communicative competence as involving the mastery of different types of texts in specific contexts" of everyday life (Richards, 2006, p. 36). Communicative competence is the ability to know how to use language and negotiate meaning with other interlocutors in contexts of daily life in order to arrive at understanding and achieve successful communication (Savignon, 2001; Richards, 2006), even if the interlocutors come from diverse cultural backgrounds. In this sense, genre-based learning aims at enhancing communicative competence through different types of spoken and written texts, including conversational exchanges and discussions of problematic and complex topics depicted in information texts (descriptions, explanations, media reports, history books), story texts (recounts, narratives, short stories, novels), and persuasive texts (opinion texts, argumentative texts, advertising, discussions, discourses, debates) (Derewianka, 2003; Richards, 2006).

Derewianka (2003) asserts that while communicative language teaching emphasizes the mastery of syntax at the level of sentence, "in genre-based approaches the emphasis is on the creation of meaning at the level of the whole text" as "meaning accumulates and evolves over a stretch of text" (p. 135). Thus, rather than studying sentences in isolation, genre-based learning empowers students for understanding content and deploying language in whole discourses in order to achieve meaning-making in more authentic ways as people do it in real life with written and spoken texts (Martin, 1999; Hyland, 2007; Herazo, 2012).

Derewianka (2003), Richards (2006), and Dirgeyasa (2016) indicate that genre-based learning methodologically involves four important stages:

In the first stage, building the context, the teacher introduces the text to students and asks them to pay attention to possible sociocultural conditions in which it was produced. Learners are incited to analyze rhetorical elements on the spoken/written text and the language used.

In the second stage, Modeling and deconstructing the text, the teacher and students discuss and analyze the text genre in detail in order to understand its social function, cultural context, communicative purpose, messages, and cultural meanings.

Even though the third stage, Joint construction, and the fourth stage, independent construction of the text, are mainly designed to ask students to construct oral or written texts that are similar to the text that has already been 
studied in the previous phases, these stages also allow learners to respond to texts critically when the focus is the reading skill. Thus, in the joint or independent construction of texts, the teacher can invite learners to do group or individual reading comprehension tasks "in response to written material such as [...] answering questions" (Richards, 2006, p. 40) and analyzing the texts at a deeper and more critical level through evaluation, judging, and making decision tasks (Derewianka, 2003). At this level, learners not only become critical readers about the messages, ideas, or thoughts in the texts or documents, but they can also compare those texts to other texts and their own reality, do further research on the topic being studied, and participate in class, debates, discussions, and written responses about the topic being discussed.

Through the stages of genre-based approach, learners can explore "features of the general cultural context in which the text type is used and the social purposes the text type achieves," and can do "cross-cultural activities, such as comparing differences in the use of the text in two cultures" (Richards, 2006, p. 39). Derewianka (2003) points out that genres or texts refer to a particular community and its social institutions. Therefore, EFL speakers learn how to participate in a new culture and to make new meanings in new cultural contexts. Similarly, Hyland (2002) states that texts are systems of cultural meanings which help understand and construct the social realities in which human beings live. Accordingly, genre-based learning promotes ICC development or cultural awareness in the communicative English classroom through texts, and recognizes that genres are naturally loaded of cultural content.

\subsection{Intercultural Communicative Competence (ICC) in EFL Education}

Idealistically, ICC develops when individuals coming from different backgrounds are able "to interact with 'others,' to accept other perceptions of the world, to mediate between different perspectives, [and] to be conscious of their evaluations of difference" in the actual process of communication (Byram, Nichols, Stevens, 2009 , p. 5). It consists of learners' ability to foster three components: (1) knowledge of one's own culture and foreign cultures; (2) positive attitudes such as curiosity, openness, and flexibility to handle strange cultural practices; and (3) skills: the skill of discovery, of interpreting, and of relating which can enable the intercultural speaker/reader to compare and contrast cultural meanings when working with texts in the classroom. These three skills will be addressed in section 2.3. It should be understood that all the components of the ICC model, knowledge, attitudes, and skills, are equally important and inseparable, one depending on the other, and are put into practice when dealing with intercultural experiences; this model being similar to the subcompetences that conform the model of communicative competence (Note 1) proposed by Canale and Swain (1980) and other later authors.

However, as explained in the statement of the problem, English learners in many EFL settings worldwide, lack opportunities to enhance their ICC because they can rarely or never interact with members of the target culture(s) or other world cultures. To counterattack this limitation, EFL teachers are called to design foreign language lessons that request students to reflect on the study of products, practices, beliefs, and perspectives of the target and other cultures in the classroom (Council of Europe, 2001; Byram, Gribkova, \& Starkey, 2002; Deardorf, 2006; McGee, 2011).

In this sense, genre-based instruction can be a pedagogical solution to foster ICC more easily in EFL classrooms, since different types of text genres contain cultural beliefs, traditions, ideologies, underlined meanings, and ways of seeing life that have been mostly adopted and shared, but equally rejected and transformed, by different groups of people or communities. Byram's (1997) states that "documents depicting another culture" (p. 52) and "authentic materials" to "promote the intercultural dimension" (Byram et al., 2002, p. 27) such as television reports, brochures, cartoons, newspaper articles, the Internet, and even the textbook can help the intercultural speaker develop ICC: The ability to infer "the implicit references to shared meanings and values [...], identify or elicit different interpretations and connotations and establish relations of similarities and difference between them" (Byram et al., 2002, p. 62). Indeed, Byram's (1997) model of ICC is an instructional model to be implemented with language learners in educational settings. In the classroom, the intercultural speaker or intercultural learner can foster his/her ICC when he/she develops the "ability to interpret a document or event from another culture, to explain it, and relate it to documents of one's own" culture (p. 52). This assertion strongly interweaves with Painter's (1996), Derewianka's (2003), and Richards's (2006) views that genres or texts are never free of the values and beliefs of their users. In this regard, in learning the genres of a culture, individuals learn how to participate in the new culture and construct new meanings in new cultural contexts.

ICC should not only be expected to be constructed in oral interaction with speakers from other cultural groups. It can also be fostered through the critical reading and interpretation of cultural meanings in "documents," texts, or genres. This teaching strategy marks a significant step to help learners start developing initial ICC in EFL 
classrooms where possibilities to interact with members of the target culture are few or are absent. In this sense, as Knutson (2006) suggests, instructional materials should include topics of low and high culture, ranging from practical aspects and products of daily life to painting, literature, political institutions, and economic matters. Experience with different materials in the EFL educational context can serve as a means to build intercultural knowledge, skills, and attitudes to understand and encounter better intercultural meanings inside and outside the classroom (Deardorff, 2006).

\subsection{Critical Thinking Skills Involved in ICC}

Critical thinking involves intellectual or mental processes of understanding, applying, evaluating, and analyzing new information that human beings receive, gather, or produce in order to solve problems, questions, or difficult situations of life from a critical and analytical perspective (Bloom, 1956; Scriven \& Paul, 1987; Anderson, \& Krathwohl, 2001; Martincová, \& Lukešová, 2014). These mental processes entail active, conscious, and purposeful awareness of what individuals encounter both in the classroom and in the outside world (Beaumont, 2010). Clearly, English learners' awareness and preparation to become intercultural speakers must involve doing critical thinking tasks that could not only help them understand, respect, and appreciate emblematic and symbolic elements of the target and other world cultures, such as music, arts, inventions, tourist places, and food, but also compare and interpret aspects of deep culture through reasoned judgments and arguments. Being intercultural means more than receiving cultural information passively. It also implies assuming a critical standpoint about cultural messages that are not always fair and neutral in intercultural communication including, for instance, unfamiliar cultural behaviors, attitudes, and ideologies on power, politics, immigration, social injustice, and human rights. Then, the skills of discovery, of interpreting, and of relating, which are relevant components of Byram's model of ICC (1997), are actually useful mental skills that generate EFL learners' critical thinking. The notion that the intercultural speaker should develop critical thinking skills is also shared by Fantini and Tirmizi (2006) who highlight that ICC is formed by a complex set of critical "abilities needed to perform effectively and appropriately when interacting with others who are linguistically and culturally different from oneself" (p. 12).

In this line of thought, in Byram's model of ICC, the skills of discovery (savoir apprendre/faire) entails "the ability to acquire new knowledge of cultural practices and the ability to operate knowledge, attitudes, and skills" in interaction (Byram, 1997, p. 61). The skills of interpreting and of relating (savoir comprendre) involve the mental "ability to analyze data from one's own and from another country and the potential relationships between them" (Byram, 1997, p. 33). These skills entail the capacity "to interpret a document or event from another culture, [and] to explain it and relate it to documents and events from one's own event" (Byram, 1997, p. 61). Thus, this reflective article argues that the three critical thinking skills of Byram's model of ICC, of discovery, of interpreting, and of relating, can be articulated and complemented with a sequence of seven specific critical thinking tasks proposed by Numrich (2006): Observing, making assumptions, understanding, interpreting, inquiring further, evaluating, and making decision tasks as indicated in Table 1, columns 2 and 3.

There are two main reasons to propose this articulation. The first one is that according to Beaumont (2010), Numrich's Sequence of Critical Thinking Tasks are especially appropriate for promoting critical thinking in foreign/second language education. The second reason is that the skills of discovering, of interpreting, and of relating "are closely related and are essential and play an important role in cases related to critical thinking skills" (Martincová \& Lukešová, 2014, p. 1257), and are "desirable skills of intercultural communication" (Martincová \& Lukešová, 2014, p. 1257). Miller (2015) equally supports the idea that critical thinking skills are essential to develop ICC, an aspect that deserves close attention in EFL education. Hence, critical thinking is linked to the goals of intercultural education which attempts to educate students as intercultural beings who are able to develop rational skills to understand, interpret, and evaluate critically others' cultural systems, behaviors, and meanings that differ from their own culture in this increasing multicultural society. Also, they constitute critical thinking tools for managing intercultural conflicts.

Accordingly, the skills of discovering, of interpreting, and of relating can be reinforced and enhanced with the use of Numrich's (2006) Sequence of Critical thinking Tasks in EFL education; they serve as specific frames of knowledge to help learners come across documents and texts from other countries in order to interpret, as Byram (1997) says, their cultural allusions and connotations. Table 1 shows how the skills of ICC model (second column) can be developed and enhanced through awareness and practice of more specific critical thinking tasks for reading purposes (third column) when implementing the stages of genre-based approach (first column). 
Table 1. Developing ICC through critical thinking tasks in a genre-based learning environment

\begin{tabular}{|c|c|c|}
\hline $\begin{array}{l}\text { Stages of genre-based } \\
\text { approach }\end{array}$ & $\begin{array}{l}\text { Critical thinking skills contained in } \\
\text { Byram's model of ICC }\end{array}$ & $\begin{array}{l}\text { Numrich's (2006) sequence of } \\
\text { explicit critical thinking tasks }\end{array}$ \\
\hline Building the context & The skill of discovery & $\begin{array}{ll}- & \text { Observing } \\
\text { - } & \text { Identifying assumptions }\end{array}$ \\
\hline $\begin{array}{l}\text { Modeling and deconstructing } \\
\text { the text }\end{array}$ & The skill of interpreting & $\begin{array}{ll}\text { - } & \text { Understanding and organizing } \\
\text { - } & \text { Interpreting/Analyzing }\end{array}$ \\
\hline $\begin{array}{l}\text { Joint construction/ } \\
\text { independent construction of the } \\
\text { text }\end{array}$ & The skill of relating & $\begin{array}{ll}- & \text { Inquiring further } \\
\text { - } & \text { Evaluating } \\
\text { - } & \text { Making decision }\end{array}$ \\
\hline
\end{tabular}

Source: This table was created by the author.

It is important to observe that Table 1 represents how the sequence of the seven explicit critical thinking tasks (third column) constitutes a scaffolding arrangement, going from the lowest to the highest and most complex order of critical thinking tasks, that could support teachers and learners with a gradual improvement of the skills entailed in ICC (second column) in a genre-based learning environment. Despite Byram's model of ICC indicates that the skills of discovery, of relating, and of interpreting develop simultaneously in intercultural learning and communication, EFL teachers must find pedagogical ways to dose slowly, progressively, and didactically the development of critical ICC in the language classroom. English teachers need to consider which explicit critical thinking tasks (third column) can be more predominantly related to each skill in Byram's model of ICC (second column) when working with genre or culture-based documents. In this way, students can realize that becoming intercultural requires preparation and awareness of not only gaining knowledge and creating positive attitudes towards otherness, but of being able to develop other specific series of skills when reading documents produced by the foreign cultures studied in class. It is a fact that becoming intercultural is not an easy task, so EFL teachers needs to find teaching strategies and follow careful steps to enhance learners' intercultural skills in setting where intercultural exposures are rare. Likewise, teachers themselves need to create awareness of the contents they ask their students to learn and the skills they request students to deploy when teaching and practicing critical thinking (Beaumont, 2010).

From this perspective, Table 1 suggests that in the first stage "Building the context" of text-based approach, EFL learners can predominantly practice two explicit critical thinking tasks, observing and identifying assumptions, to enhance ICC's skill of discovery when they are asked to work with a given text. Similarly, the explicit critical thinking tasks understanding, interpreting, and analyzing can be predominantly practiced to reinforce ICC's skill of interpreting in the second stage of genre-based learning called "Modeling and deconstructing the text." Finally, learners can predominantly do inquiring further, evaluating, and making decision tasks to enhance ICC's skill of relating when being asked to work on the stage "Joint or independent construction of the text," the last methodological step of genre-based approach. Following this scaffolding and progressive order aims at helping EFL learners construct ICC more purposely, didactically, and gradually, taking into account that the study of texts, from the perspective of genre-based approach, must follow a step-by-step learning progress.

\section{Example of Implementing Genre-Based Approach to Enhance ICC Through Critical Thinking Tasks}

To illustrate how learners can be engaged in building ICC in the language classroom from a gender-based approach, two readings were chosen:

Reading One:

Reading one, "Everyday people changing the world" (Figure 1), is an example of an average reading that EFL learners can easily find in English communicative textbook used in many schools. This sample is part of a reading activity taken from an intermediate level textbook. It incorporates sporadic, emblematic, and representative elements of surface culture of two countries, but lacks elements of deep culture. Also, the units of the textbook are designed to study grammar in context. Thus, the reading task in Figure 1 presents the topic of two people who created charity foundations to help impoverished children at two geographical sites, Kliptown in South Africa and Nepal, these geographical names being the only cultural information provided in the reading. One of the issues presented in this reading, children born in prisons in Nepal, is never addressed from an intercultural perspective. 


\section{EVERYDAY PEOPLE CHANGING THE WORLD}

Thulani Madondo started an educational programme to help children living in the slums of Kliptown, South Africa. When Thulani left primary school, his father told him that he didn't have enough money for his high school fees. Thulani washed cars and carried boxes to earn his own money to pay to go to school. The Kliptown Youth Program helps other young people in Kliptown to get an education and improve their lives. It gives them uniforms, books and money for their school fees.

Pushpa Basnet runs a day care centre for children who are growing up in prison in Nepal. Pushpa studied social work at university. One day when she visited a women's prison, she saw children living there. She was shocked by this situation and she opened a children's day care centre.

Every day, children under the age of six leave prison in the morning to spend the day at the centre. Pushpa also runs a residential home for older children who have the chance to go to school and get food and health care.

Figure 1. Reading one. Sample of a textbook reading selection

The purpose of Reading One is rather to help intermediate EFL learners study the grammar structure simple past tense of regular verbs in English, as the regular verbs in the reading are underlined, leading them to practice the communicative function talking about past events. In the textbook, students are asked to read this selection and complete a table based on the information it provides in order to practice reading comprehension. Then, they are asked to pay attention to the underlined verbs in the reading in order to answers some question on grammar use. It can be observed that this reading lacks deeper cultural contents that could help learners develop ICC. Therefore, in cases like this, the English teacher can complement this first type of reading with a similar culture-based topic. Since the topic of this reading is children's hardship in other cultures, the teacher can use other texts and sources and cultural backgrounds in order to foster critical ICC from a genre-based approach as illustrated in Reading Two (Figure 2).

\section{Reading Two:}

Reading Two, "No life for a child: The grim reality of Nepal's child laborers" (Bhandari, 2013) (Figure 2), an authentic and adapted news article taken from the CNN web page in Asia, is a genre sample that addresses child labor in Nepal, a cultural topic that is far from being congratulatory and emblematic, but rather controversial, belonging to the level of deep culture. This genre produced in a foreign cultural site is useful material to enhance critical ICC.

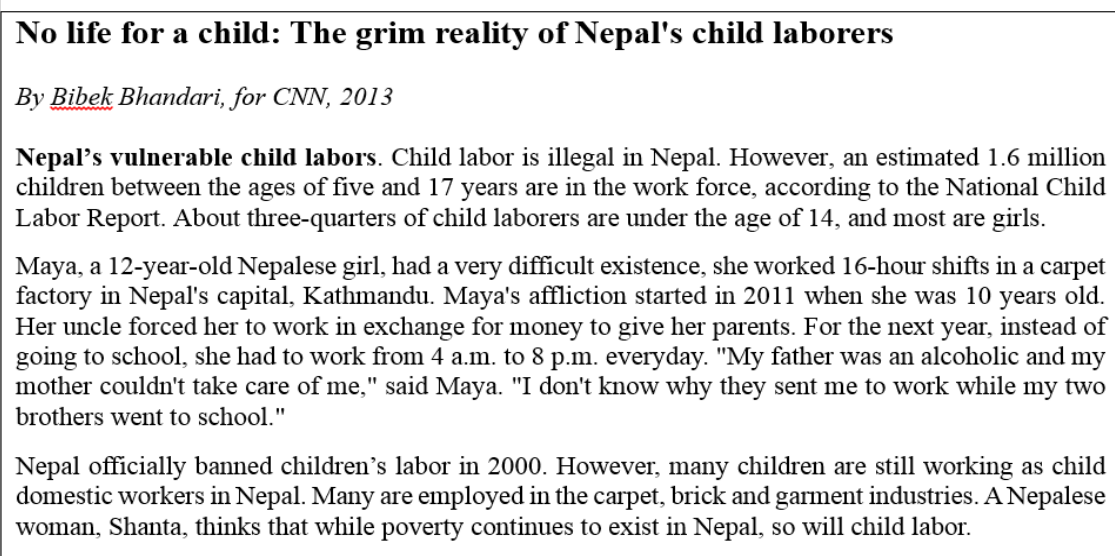

Figure 2. Reading two. Sample of information genre: A news article

Source: Retrieved and adapted from CNN News

https://edition.cnn.com/2013/08/14/world/asia/nepal-child-labor/index.html

In the first stage of genre-based approach, Building the context, learners can be introduced to the sociocultural 
context in which the text (news article) was produced. To do so, learners can be initially stimulated to work on the skill of discovery of new knowledge related to ideologies about labor exploitation of children in another country, leading them to do the first explicit critical thinking tasks observing and identifying assumptions as suggested in Table 1. With these skills, they can start comprehending the news article in context. With the support of a world map, the teacher can ask questions such as:

- Do you know where Nepal is located in the map?

- What is the capital of Nepal?

- What language do people speak in Nepal?

- What cultural information do you know about Nepal?

Observing and identifying assumptions, two basic critical thinking tasks, can prepare intermediate EFL learners to study new vocabulary and language. They also help learners to explore the topic on how other cultures in the world share the cultural belief that children have to work to support their parents economically. These critical thinking tasks equally help learners discover what they know or need to learn about the topic, activate their prior knowledge, and prepare them to use higher order of critical thinking tasks.

In the case of the skill identifying assumptions, in particular, learners can be invited to pay attention to the news headline, to look at several photographs of Nepalese children that appear in the CNN web site, or to look at other photographs of children bounded to work in Nepal brought by the teacher. Learners can make predictions, attempting to identify and discover deep cultural messages in the news. Thus, the headline "No life for a child" and "grim reality" may help learners infer that Nepalese children's life is difficult because they are forced to work. Similarly, the name of the author's news article, Bybek Bhandari, can lead learners to identify the assumption that he is probably a reporter from Nepal or a nearby country like Japan or India in Asia. With the teacher's clarification, learners can discover that the cultural event or cultural practice presented in this document is reported by a member of the Nepalese or Asian community, who is talking about a controversial issue of his own culture. By identifying assumptions, a useful critical thinking task in the initial stage Building the context suggested by genre-based approach, learners can enhance ICC's skill of discovering as they react to words in the headline, the visual materials, and the content they see or hear, share previous knowledge, and express opinions based on culture-based materials.

In the second stage of genre-based approach, Modeling and deconstructing the text, the teacher and students read and discuss the news article directly in order to understand detailed information, its purpose, and sociocultural events (Richards, 2006; Derewianka, 2003). In this stage, learners can develop predominantly the critical thinking tasks understanding and interpreting, this being a way to enhance the skill of interpreting as proposed by the ICC model (see Table 1). Understanding and interpreting critical thinking tasks progressively motivate learners to read the cultural issues conveyed in the text more critically. Thus, understanding comprises several mental subskills to focus on the text, namely constructing meaning from the written words, reading and looking at new information, identifying previous information they know, scrutinizing vocabulary or structures to achieve clarity, and organizing the logical connections among sentences and paragraphs. Moreover, learners can recognize the main cultural topic or conflict in the news article, considering, for instance, why child labor exits in Nepal and which are some of the values and beliefs that define family and children in this foreign culture. Although understanding is a basic critical thinking skill, it constitutes an active decisive factor to lead EFL learners to interpret the text. Hence, learners can be encouraged to answer these questions, leading them to do the critical thinking task understanding with the article news:

- Is child labor legal or illegal in Nepal?

- How many hours did Maya work in a carpet factory?

- What's your opinion about it? Who forced Maya to work in a carpet factory?

- Why do children have to work in Nepal? Which cultural values, traditions, and practices does the news article reveal about labor and family in Nepal?

In this same stage of genre-based approach, Modeling and deconstructing the text, intermediate learners can also develop the critical thinking task interpreting (see Table 1) as they begin to see below the literal surface of the text, make inferences, interpret meaning, and hypothesize based on words, sentences, and information they encounter in the text (Beaumont, 2010). Learners can interpret cultural meanings when they are encouraged to answer initial opinion-based questions on the cultural issue being discussed. For example, some questions leading learners to do interpreting tasks about the news article are: 
- What is the reporter's attitude toward child labor in Nepal?

- Do you agree or disagree with his attitude?

- Why do you think the reporter says that child labor is "vulnerable" in Nepal?

- What Nepalese cultural belief/practice about women's and men's roles in society is reflected in Maya's words, "I don't know why they sent me to work while my two brothers went to school"?

- What is the meaning of Shanta's statement, “while poverty continues to exist in Nepal, so will child labor"?

- What cultural and social reality does Shanta speak about in this statement?

These questions are focused on interpreting the text directly as learners scrutinize critically and infer the cultural meanings about child labor in Nepal by considering evidence and rational arguments in their interpretations. Learners can discuss, for instance, that the reporter seems to disagree with the cultural practice that children should work in Nepal as he associates child labor with affliction, grim, and a difficult existence. Learners can also discuss conflictive topics of deep culture such as the fact that parents force children to work for long hours despite child labor was prohibited in Nepal in 2,000; this being a difficult cultural practice for old generations to change. Equally, learners can discuss the importance that Nepalese parents and children give to labor and employment in comparison to their views on education, as labor means bringing home money and food to survive. Intermediate EFL learners can also be encouraged to interpret implied messages in the news article about the fact that sexist and patriarchal power is established in Nepal, because parents force their daughters to work in factories while send their male children to school. Similarly, they can analyze the disadvantages and effects of poverty on children population in Nepal.

Hence, understanding and interpreting tasks can empower learners to pay attention to all the parts, meanings, and relationships that exist in all the text (Anderson \& Krathwohl, 2001). These critical thinking skills not only help learners understand rooted cultural ideologies established in other nations, but also build their skill of interpreting as conceived by ICC at the level of their own critical capacities and English language proficiency. Then, it can be seen that text-based approach can foster ICC in the EFL context when students not only have the opportunity to use the foreign language meaningfully, but also, as Byram et al. (2002) state, can interrogate and interpret texts and documents critically in order to understand other cultures.

In the last stage of genre-based approach, joint and independent construction of texts, learners can be invited to go further the cultural information they understand and interpret in the texts by establishing connections with other documents or by relating the topics in the text to their own or other's reality and cultures. That is why this stage is ideal to mainly practice the skill of relating, the third critical thinking skill that defines ICC. To clearly illustrate how EFL learners can enhance the skill of relating through genre-based approach, these questions can be asked after students had worked with the news article "No life for a child: The grim reality of Nepal's child laborers":

- Do some children work in your country? Where and why do they work? What is your opinion about it?

- Do you work or study? What is your parents' opinion about child labor in your country? Do you share their opinion?

- $\quad$ Is child labor a legal or illegal cultural practice in your country?

- Which rights should children have in all cultures?

These questions establish a bridge between the foreign cultural situation that learners read in the news article and their own culture, inviting them to express opinions based on ideologies and beliefs adopted in their own country as well. Furthermore, the skill of relating can primarily be practiced through three explicit higher order critical thinking tasks proposed by Numrich (2010): inquiring further, evaluating, and making decisions. In this sense, learners can do inquiring further tasks through genre-based approach when the teacher triggers their curiosity and investigative spirit to find similar pieces of news about cultural conceptions of child labor in other countries of the world. As Numrich (2006) and Beaumont (2010) suggest, students can seek out new information related to the topic that they are exploring, not only depending on the primary text, a shared idea by genre-based approach. Within this frame, learners do inquiring further tasks such as interviewing experts on the topic or people involved in the phenomenon, like in this case, child labor, and doing research in the library or the Internet to find additional articles and videos. Genre-based learning upholds the need to complement the genres with "other texts in the same or similar [cultural] context" and do research on "other text types used in the same field" (Richards, 2006, p. 41). During this inquiry process, learners also start making decisions about the perspective of the topic 
they want to discuss, about the cultural group they want to choose, whether their own or another culture, and the specific information they want to report in class time, an important steps of inquiring further task.

After learners have expanded their intercultural knowledge during the study of the text, including inquiring tasks through the methodological stages of genre-based approach, they can finally practice the most complex critical thinking tasks, evaluating (see Table 1), a cognitive level that involves "making judgments based on criteria and standards through checking and critiquing" (Anderson \& Krathwohl, 2001, p. 83). Making judgments involves the ability to make well-thought-out decisions and sensible conclusions as a result of the opinions on the evidence found in the primarily text, the news article, and of the inquiry process of all the additional texts and sources they have collected to analyze the cultural topic. Examples of evaluating the news article can be triggered through questions involving final judgments on cultural contents of the native and the foreign culture(s):

- What is your opinion about child labor in Nepal and Colombia/Peru/Mexico?

- Explain why children should/should not work in any part of the world.

- Design a campaign to stop child labor in Nepal or in your country.

- Say in which way child labor favors or affects children's personality and future lives in your own culture.

- Relate the difficult situation of children who are forced to work in Nepal to similar situation of labor

exploitation in your own culture or another.

Therefore, in this stage, joint and independent construction of texts, learners can evaluate, criticize, and assume a position about cultural phenomena, beliefs, lifestyles, and practices, and make wise decisions whether they agree, disagree with, value or reject different cultural precepts in their own culture and in foreign ones. Students can write and report orally short arguments to practice the skill evaluating based on their own learning pace and language proficiency. By comparing, evaluating, and making decisions tasks on sociocultural problems that exist between two or more cultural communities, learners can enhance ICC's skill of relating in the language classroom.

\section{Limitations With the Use of Genre-Based Approach for ICC Development}

For those unfamiliar with genre-based approach, working with comprehension, analysis, interpretation, and discussion of texts is a time-consuming task. Teachers and learners must be patient and eager to develop the whole process, since the idea is to scrutinize the whole text in terms of language forms, communicative purpose, and cultural meanings. Also, as Richards (2006) asserts, it is important to understand that genre-based approach organizes learning around a framework of texts rather than around communicative functions and grammar forms at the level of sentence formation as usually done in EFL classrooms.

Another demanding condition is the inclusion of original versions of genres which, at the beginning, can make EFL learners anxious about working with authentic language because they are used to study English through gradual presentation and practice of language contents in communicative textbooks. So, the selection of authentic materials should be suitable for English learners' level. If necessary, teachers can make minimum adaptations and modifications to the texts to accomplish motivating levels of readability.

Enhancing the components of ICC to a greater or lesser degree is also a time-consuming task because it is not an innate ability. It requires a constant process of awareness, practice, and commitment to construct attitudes (curiosity, readiness, openness) and foster the skills of discovery, of interpreting, and of relating. Teachers and students must be aware that the model of ICC is an educational proposal with learning objectives to be used in educational settings, aiming at preparing them to be more aware of cultural differences when interacting in real communication with human beings from diverse backgrounds and origins inside and outside the language classroom.

\section{Conclusions}

It is a fact that ICC is still difficult to be developed in EFL education because English teachers generally emphasize the study of language forms and communicative functions. They also feel unprepared to teach foreign cultural contents due to lack of knowledge and methodologies. In this regard, genre-based learning can be a tangible, visible, and didactic approach that can help teachers to be more prepared and conversant with cultural contents as they can learn to identify and interpret the cultural meanings in documents produced by other communities. In turn, teachers can help learners enhance the skills of discovery, of interpreting, and of relating with the support of diverse genres such as news articles, songs, movies, narratives, short stories, and the like. The EFL teacher is not expected to know and teach all the cultural information of other communities or nations, 
but rather to help learners develop critical thinking skills that could lead them to discover and interpret implicit cultural meanings in different types of foreign genres and documents, which are materials naturally imbued of cultural messages.

More than studying general cultural information belonging to surface, observable, and neutral elements of culture, there should be an emphasis on the discussion and analysis of elements of deep culture in texts such as viewpoints on power relations, discrimination, stereotypes, and social injustice. For instance, with the news article sample presented in this article, learners are invited to discuss critically complex issues on child labor, the effects of poverty, social oppression, gender inequality, the power of institutions, and political laws. Developing the skills involved in the ICC model may help learners deal with deep, complex, and sometimes controversial ideologies and beliefs.

Implementing Numrich's (2006) Sequence of Critical Thinking Tasks can reinforce learners' ICC, as ICC is not only composed of knowledge and attitudes, but also of critical thinking skills: of discovery, of interpreting, and of relating. The English teacher and learners should practice this Sequence of Critical Thinking Tasks in an orderly fashion by keeping in mind that the use of this framework should be conscious, gradual and slow because becoming critical requires systematic effort and time. In order to complete this pedagogical procedure successfully, teachers should also keep in mind that some of Numrich's (2006) critical thinking task can be more predominantly related to one of the three skills that conform the concept of ICC. Implementing them from the lower to the higher order can direct the learning process to accomplish goals at a critical stand.

Even though many EFL learners cannot experience direct intercultural communication with members of other language communities through English in their own home countries, precisely because English is not the official language and learners have reduced possibilities to travel abroad, they can enhance ICC in the educational contexts through texts, genres, and documents. The English class should be a space to educate learners to gradually become intercultural citizens of the world, so that at any moment of their lives they are prepared and aware of facing the socioeconomic and intercultural challenges of a day-to-day more interconnected society.

\section{References}

Anderson, L. W., \& Krathwohl, D. R. (2001). A taxonomy for learning, teaching and assessing: A revision of Bloom 's Taxonomy of Educational Objectives. White Plains, NY: Longman.

Beaumont, J. (2010). A sequence of critical thinking tasks. TESOL Journal, 1(4), 427-488. https://doi.org/10.50 $54 / \mathrm{tj} .2010 .234763$

Bhandari, B. (2013, August, 15). No life for a child: The grim reality of Nepal's child laborers. Retrieved from https://edition.cnn.com/2013/08/14/world/asia/nepal-child-labor/index.html

Bloom, B. S. (1956). Taxonomy of educational objectives. Boston, MA: Allyn \& Bacon.

Byram, M. (1997). Teaching and assessing intercultural communicative competence. Clevedon: Multilingual Matters.

Byram, M., Gribkova, B., \& Starkey, H. (2002). Developing the intercultural dimension in language teaching: A practical introduction for teachers. Strasbourg: Council of Europe.

Byram, M., Nichols, A., \& Stevens, D. (2009). Developing intercultural competence in practice. Exeter, England: Cromwell Press.

Canale, M., \& Swain, M. (1980). Theoretical bases of communicative approaches to second language teaching and testing. Applied Linguistics, 1, 1-47. https://doi.org/10.1093/applin/I.1.1

Council of Europe. (2001). Common European framework of reference for languages. Cambridge: Cambridge University Press.

Crozet, C., \& Liddicoat, A. (2000). Teaching Languages, Teaching Cultures. Melbourne: Language Australia.

Deardorff, D. K. (2006). Identification and assessment of intercultural competence as a student outcome of internationalization. Journal of Studies in International Education, 10(3), 241-266. https://doi.org/10.117 $7 / 1028315306287002$

Derewianka, B. (2003), Trends and issues in genre-based approaches. RELC Journal, 34(2), 133-154. https://doi.org/10.1177/003368820303400202

Dirgeyasa, I. W. (2016). Genre-Based Approach: What and How to Teach and to Learn Writing. English Language Teaching, 9(9), 45-51. https://doi.org/10.5539/elt.v9n9p45 
Dogankay-Aktuna, S. (2005). Intercultural communication in English language teacher education. ELT Journal, 99-107. https://doi.org/10.1093/eltj/cci023

Fantini, A. E. (1999). Comparisons: Towards the development of intercultural competence. In J. K. Phillips (Ed.). Foreign language standards: Linking research, theories, and practices (pp. 165-217). Lincolnwood, IL: National Textbook.

Fantini, A., \& Tirmizi, A. (2006). Exploring and assessing intercultural competence. World Learning Publications. Paper 1. Retrieved from http://digitalcollections.sit.edu/worldlearning_publications/1

$\mathrm{Gu}, \mathrm{X}$. (2016). Assessment of Intercultural Communicative Competence in FL Education: A Survey on EFL Teachers' Perception and Practice in China. Language and Intercultural Communication, 16(2), $254-273$. https://doi.org/10.1080/14708477.2015.1083575

Herazo, J. D. (2012). Using a genre-based approach to promote oral communication in the Colombian English classroom. Colombian Applied Linguistic Journal, 14(2), 109-129. https://doi.org/10.14483/udistrita 1.jour.calj.2012.2.a07

Hesar, M.; Konka, M., \& Sarfsaz, E. (2012). Why and How to Apply Culture in an EFL Classroom? International Conference on Language, Medias and Culture, IPEDR, 33. Retrieved from http://www.ipedr.com/vol33/014-ICLMC2012-L00030.pdf

Hinkel, E. (2001). Building awareness and practical skills to facilitate cross-cultural communication. In M. Celce-Murcia (Ed.), Teaching English as a second or foreign language (3rd ed., pp. 443-358). Boston,MA: Heinle Cengage Learning.

Hyland, K. (2002). Genre: Language, Context, and literacy. Annual Review of Applied Linguistics, 22, 13-35. https://doi.org/10.1017/S0267190502000065

Hyland, K. (2007). Genre pedagogy: Language, literacy and L2 writing instruction. Journal of Second Language Writing, 16(3), 148-164. https://doi.org/10.1016/j.jslw.2007.07.005

Kramsch, C. J. (1993). Context and culture in language teaching. Oxford: Oxford University Press.

Knutson, E. (2006). Cross-Cultural Awareness for Second/Foreign Language Learners. The Canadian Modern Language Review, 62(4), 591-610. https://doi.org/10.3138/cmlr.62.4.591

Martin, J. (2009). Genre and language learning: A social semiotic perspective. Linguistics and Education, 20, 10-21. https://doi.org/10.1016/j.linged.2009.01.003

Martincová, J., \& Lukešová, M. (2015). Critical Thinking as a tool for managing intercultural conflicts. Procedia: Social and Behavioral Sciences, 171, 1255-1264. https://doi.org/10.1016/j.sbspro.2015.01.239

McGee, A. R. (2011). Climbing walls: Attempting critical pedagogy as a 21 st century preservice teacher. Language Arts, 88(4), 270-277.

Miller, J. W. (2015). Addressing and assessing critical thinking in intercultural contexts: Investigating the distance learning outcomes of military leaders. International Journal of Intercultural Relations, 48, $120-136$. https://doi.org/10.1016/j.ijintrel.2015.07.002

Moeller, A. K., \& Nugent, K. (2014). Building intercultural competence in the language classroom. Faculty Publications: Department of Teaching, Learning and Teacher Education.

Numrich, C. (2006). Face the issues: Intermediate listening and critical thinking skills (3rd ed.). London: Pearson Higher Education.

Numrich, C. (2010). Raise the issues: An integrated approach to critical thinking. Upper Saddle River, NJ: Pearson.

Painter. C. (1996). The development of language as a resource for thinking: A linguistic view of learning. In R. Hasan, \& G. Williams (Eds.), Literacy in society (pp. 58-75). London: Longman.

Pauwels, A. (2000). Globalisation and the Impact of Teaching Languages in Australia. In C. Crozet, \& A. Liddicoat (Eds.), Teaching languages, teaching cultures (pp. 19-26). Melbourne: Language Australia.

Richards, J. (2006). Communicative language teaching today. Cambridge: Cambridge University Press.

Savignon, S. (2001). Communicative language teaching for the twenty-first century. In M. Murcia (Ed.), Teaching English as a second/foreign language (pp.12-28). Boston, MA: Heinle \& Heinle.

Scriven, M., \& Paul, R. (1987). Defining Critical Thinking [online]. Foundation for Critical Thinking, (C) 2011, 
[cit. 2012-01-02]. Retrieved from http://www.criticalthinking.org/pages/defining-critical-thinking/766

Seidlhofer, B. (2005). English as a lingua franca. ELT Journal, 59(4), 339-341. https://doi.org/10.1093/elt/cci064

Sercu, L. (2006). The foreign language and intercultural competence teacher: The acquisition of a new professional identity. Intercultural Education, 17(1), 55-72. https://doi.org/10.1080/14675980500502321

Shaules, J. (2007). Deep culture: The hidden challenges of global living. Clevedon, UK: Multilingual Matters. https://doi.org/10.21832/9781847690180

Young, T. J., \& Sachdev, I. (2011). Intercultural communicative competence: Exploring English language $\begin{array}{lllll}\text { teachers' beliefs and practices. Language Awareness, } & 20(2), & 8198 .\end{array}$ https://doi.org/10.1080/09658416.2010.540328

\section{Note}

Note 1. According to Canale and Swain (1980), communicative competence is divided into grammatical competence, sociolinguistic competence, and strategic competence, all these components (subcompetences) together enables speakers to communicate and negotiate meaning in contexts of real life. This model has been refined by other authors, including Backman \& Palmer (1979), and Savignon (2001).

\section{Copyrights}

Copyright for this article is retained by the author(s), with first publication rights granted to the journal.

This is an open-access article distributed under the terms and conditions of the Creative Commons Attribution license (http://creativecommons.org/licenses/by/4.0/). 